\title{
Foundation Funding for Arts Education
}

AN O VERVIEW O F RECEN T TREN DS

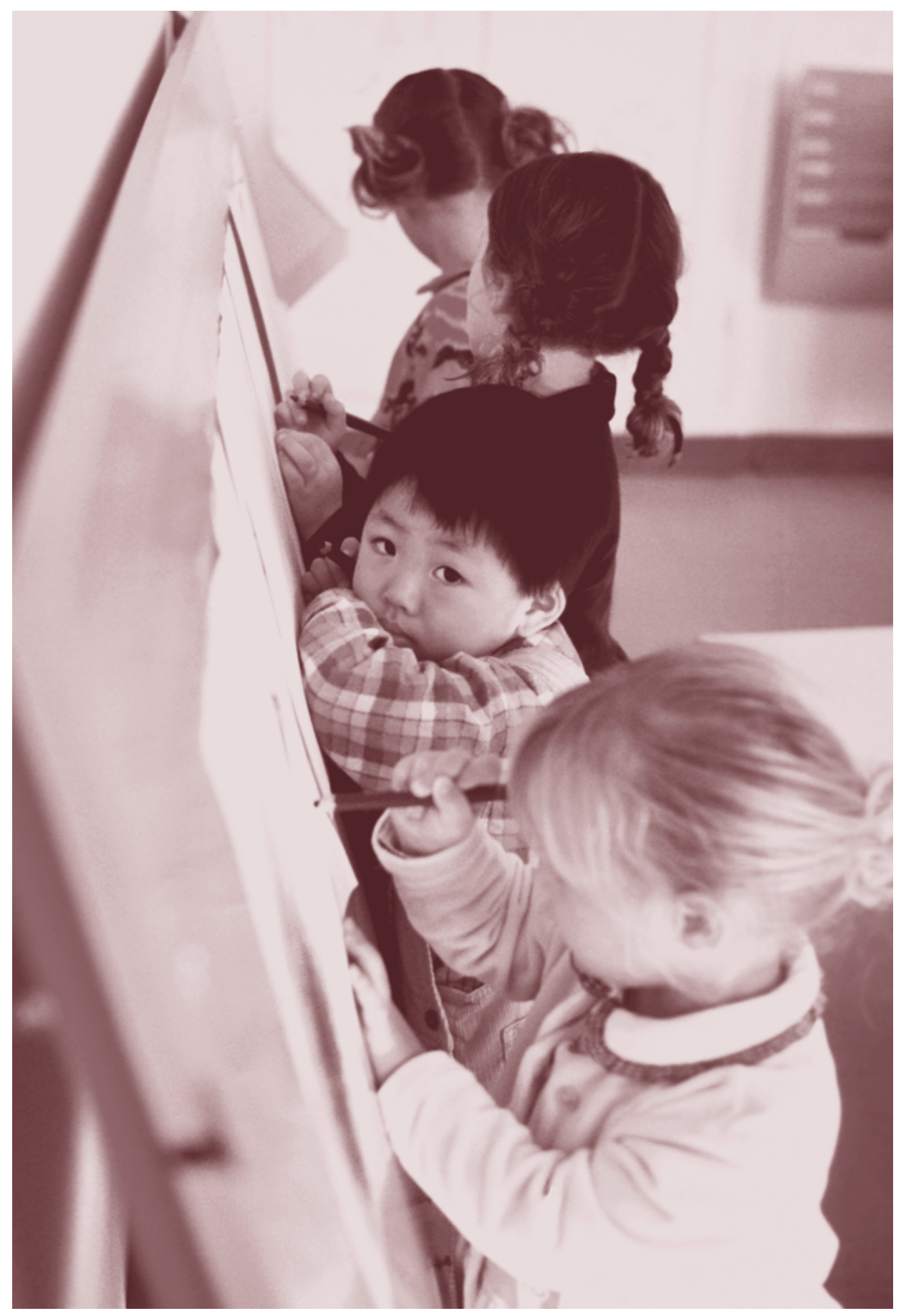

\section{Loren Renz}

Vice President for Research

Josefina Atienza

Research Analyst/Coordinator

of the Foundations Today Series
The Foundation Center

in cooperation with

G rantmakers in the Arts

O CTO BER 2005 


\section{FOUNDATION FUNDING FOR ARTS EDUCATION STEERING COMMITTEE}

Advisors:

Jeanne Butler, Chair

American Architectural

Foundation

Jacky Alling

Arizona Community

Foundation

Beth Feldman Brandt

Stockton Rush Bartol

Foundation

Moy Eng

William and Flora Hewlett

Foundation

Deena Epstein

George Gund Foundation

Jonathan Katz

National Assembly of State

Arts Agencies

For Grantmakers in the Arts:

Rory MacPherson
Wallace Foundation
Susan McCalmont
Kirkpatrick Foundation
Ed Pauly
Wallace Foundation
Frances Phillips
Walter and Elise Haas Fund
Janet Sarbaugh
Heinz Endowments
Sarah Solotaroff
Chicago Community Trust

Rory MacPherson

Wallace Foundation

Ed Pauly

Wallace Foundation

Frances Phillips

Walter and Elise Haas Fund

Janet Sarbaugh

Sarah Solotaroff

Chicago Community Trust
Anne Focke

Julie Sponsler

For the Foundation Center:

Loren Renz

Steven Lawrence

Josie Atienza

Asmita Barve

Contributing Staff:

Ashley Bailey

Research Assistant

Kathye Giesler

Publishing Database Administrator

Christine Innamorato

Production Coordinator, Publications

\section{ACKNOWLEDGMENTS}

The Foundation Center and Grantmakers in the Arts (GIA) wish to thank Beth Feldman Brandt and Rory MacPherson for their invaluable comments on a draft of the study. Special thanks are also due to Julie Sponsler for serving as principal project liaison for GIA. The Center also gratefully acknowledges the Wallace Foundation for providing funding for this report.

\section{ABOUT THE FOUNDATION CENTER}

The Foundation Center's mission is to strengthen the nonprofit sector by advancing knowledge about U.S. philanthropy.

To achieve our mission, we:

- Collect, organize, and communicate information on U.S. philanthropy

- Conduct and facilitate research on trends in the field

- Provide education and training on the grantseeking process

- Ensure public access to information and services through our Web site, print and electronic publications, five library/learning centers, and a national network of Cooperating Collections.

Founded in 1956, the Center is the nation's leading authority on philanthropy and is dedicated to serving grantseekers, grantmakers, researchers, policymakers, the media, and the general public.

\section{ABOUT GRANTMAKERS IN THE ARTS}

Grantmakers in the Arts (GIA) is a membership organization whose trade is discourse on ideas about arts philanthropy within a diverse community of grantmakers. Founded in 1985, GIA maintains a lightweight infrastructure that supports its members' work together. Members include private, community, corporate, and family foundations, as well as public sector grantmakers, regranting organizations whose primary purpose is arts grantmaking, and individual donors who give through eligible organizations. GIA programs include an annual conference, a major periodical, research, and other convening and communication services.

\section{ABOUT THE REPORT SPONSOR}

The Wallace Foundation supports and shares effective ideas and practices that help institutions expand learning and enrichment opportunities for all people. Its current goals are to: strengthen education leadership to improve student achievement; improve out-of-school time learning opportunities; and expand participation in arts and culture.

Copyright (C) 2005 The Foundation Center. For more information, contact Josie Atienza at 212-620-4230, or email, jsa@fdncenter.org. Foundation Funding for Arts Education can be downloaded from www.fdncenter.org/ research or at www.giarts.org. 


\section{Foundation Funding for Arts Education}

T The arts are central to all civilizations. They provide a means for personal and political expression, for conveying ideas and emotions, and for preserving cultural knowledge from generation to generation. This makes the role of those working to pass along an understanding and appreciation of the arts and the skills needed to perpetuate and enhance their many forms especially critical.

Foundations have long supported arts education as a means for building artistic skills and cultivating a life-long appreciation of the arts. They have also understood that the benefits of arts education go far beyond building audiences and inspiring future artists. Research has demonstrated the value of arts education for early intellectual development and later academic achievement—especially among those most at risk. ${ }^{1}$ In a period of diminished public support for arts education, therefore, foundation funding in this area takes on even greater importance.

To document the size and scope of art education grantmaking by U.S. foundations, the Foundation Center, in collaboration with Grantmaker in the Arts, has prepared Foundation Funding for Arts Education. (For the definition of arts education used in this
GRANTMAKERS IN THE ARTS (GIA) WORKING GROUP ON ARTS EDUCATION

GIA's support of this study coincides, not accidentally, with increased interest in arts education among GIA members. A number of members who have been working on discrete arts education initiatives have formed a working group to give focus to this collective interest. The group will address the fragmentation that exists in arts education nationally and will discuss the fundamental question of why they promote the teaching of the arts.

Funding for arts education grew faster than arts giving overall from 1999 to 2003

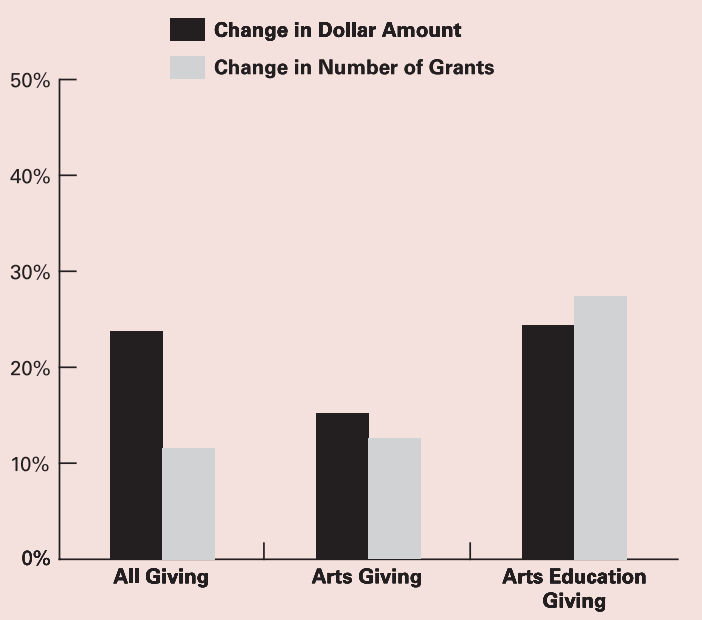

Based on all grants of $\$ 10,000$ or more awarded by 1,016 larger foundations for 1999 and 1,010 for 2003 . Only grants to organizations are included. 


\section{Sampling Base}

The information presented in this report is based on the Foundation Center's annual grants sets. Each set includes all of the grants of $\$ 10,000$ or more awarded to organizations by just over 1,000 of the largest U.S. foundations and represents roughly half of total grant dollars awarded by the universe of independent, corporate, community, and grantmaking operating foundations in that year. Specifically, the 2003 grants set included 120,721 grants awarded by 1,010 foundations totaling $\$ 14.3$ billion; and the 1999 set included 108,169 grants awarded by 1,016 foundations totaling $\$ 11.6$ billion. Grants to individuals and grants from donor-designated and restricted funds of community foundations are not included. (See Appendix A in Foundation Giving Trends for complete sampling information.)

\section{IDENTIFYING ARTS EDUCATION GRANTS}

Consistent with the definition of arts education funding employed for this report (see "Defining Arts Education Grantmaking”), the following analysis includes all grants with a primary or secondary grant purpose or recipient type code for arts education or performing arts education; a primary grant purpose code for multidisciplinary arts, folk arts, arts councils, visual arts, art museums, ethnic/folk art museums, children's museums, performing arts, literary services, and arts and artist's service activities and a secondary grant purpose code for education (excluding libraries); and a primary grant purpose code of education (excluding libraries), camps, and youth development and a secondary grant purpose code for multidisciplinary arts, folk arts, arts councils, visual arts, art museums, ethnic/folk art museums, children's museums, performing arts, literary services, and arts and artist's service activities. study, see "Defining Arts Education Grantmaking.") The most comprehensive analysis of foundation arts education support available, the report examines the distribution of arts education funding in 2003 and changes in giving since 1999. ${ }^{2}$ It also includes brief profiles of leading arts education grantmakers across the country, which demonstrate the wide variety of strategies employed by these funders to strengthen arts education.

\section{Defining Arts Education Grantmaking}

For the purpose of this study, arts education grantmaking has been divided into the major areas of multidisciplinary arts education, performing arts education, visual arts education, museum arts education, and literary arts education and broadly defined as supporting:

- Single-discipline and multidisciplinary artsin-education and arts and education organizations and programs

- Educational activities and outreach programs of museums, performing arts companies, visual arts centers, and other arts groups

- Development of arts curriculum, arts-related classroom space, and arts and performing arts facilities at schools, colleges, and universities

- Scholarships, fellowships, and residencies for young and emerging artists provided through arts groups and degree-granting arts institutions

- Community arts schools and arts education programs conducted by multipurpose community organizations and youth development groups

- Research on the role and effectiveness of arts education and advocacy to expand and enhance its influence 


\section{Trends in Arts Education Funding, 1999 through 2003}

Between 1999 and 2003, the country traveled from an unprecedented economic boom, through a stock market downturn and recession, and into a shaky and uneven economic recovery. Despite these dramatic swings, giving for arts education by funders included in the Foundation Center's annual grants set (see "Sampling Base" for details) rose 24 percent, from \$167.9 million to $\$ 208.8$ million. This gain (unadjusted for inflation) matched the increase in overall foundation giving recorded during this period and surpassed the 15.2 percent growth in arts funding overall. As a result, arts education's share of total arts funding increased slightly to nearly 12 percent. By number of grants, arts education support grew 28 percent, from roughly 2,400 to over 3,100 .

Although giving for arts education was notably higher in 2003 than in 1999, growth was not consistent throughout this period. Much of the rise in funding occurred between 1999 and 2001, when arts education support increased annually at double-digit rates. Grant dollars for the field peaked at $\$ 245$ million in 2002, before declining 15 percent in 2003. Similarly, funding for the arts overall experienced strong growth between 1999 and 2001, but peaked at \$2 billion in 2001, before declining 5 percent in 2002 and 8 percent in 2003. These trends were consistent with changes in foundation giving overall.

The trend in arts funding partly reflected changes in the number of foundations in the sample making arts education grants. The number of arts education funders rose from 520 in 1999 to close to 580 in 2001 and 2002, before slipping back to 549 in 2003 .

The Kresge Foundation led all other funders by amount of giving for arts education in 2003, with nine capital grants totaling $\$ 9.4$ million. If capital grants were excluded, the Annenberg Foundation would have ranked as the top arts education funder. Annenberg made 21 non-capital arts education grants totaling \$5.9 million in the latest sample, with close to half of this funding supporting the New York City-based Center for Arts Education. Its overall arts education support totaled $\$ 9.2$ million. Still, neither of these foundations provided more than 10 percent of their total grant dollars for arts education. In fact, only eight of the top 25 arts education

\section{Key Findings}

- Support for arts education grew faster than arts giving overall from 1999 to 2003

- Performing arts education benefited from over half of arts education giving

- Arts organizations received four out of five arts education dollars and grants

- A majority of arts education grants targeted children and youth through in-school programs and other arts education programs

- Northeastern foundations provided the largest share of grant dollars awarded for arts education; the Northeast also accounted for the biggest share of dollars received

\section{Arts education represented a slightly larger share of overall arts giving in 2003}

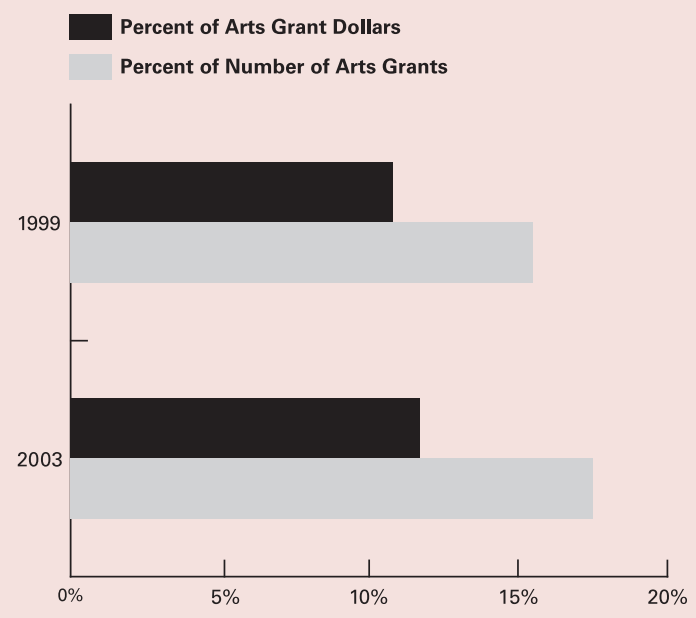

Based on all grants of $\$ 10,000$ or more awarded by 1,016 larger foundations for 1999 and 1,010 for 2003 Only grants to organizations are included. 
Arts education giving peaked in 2002

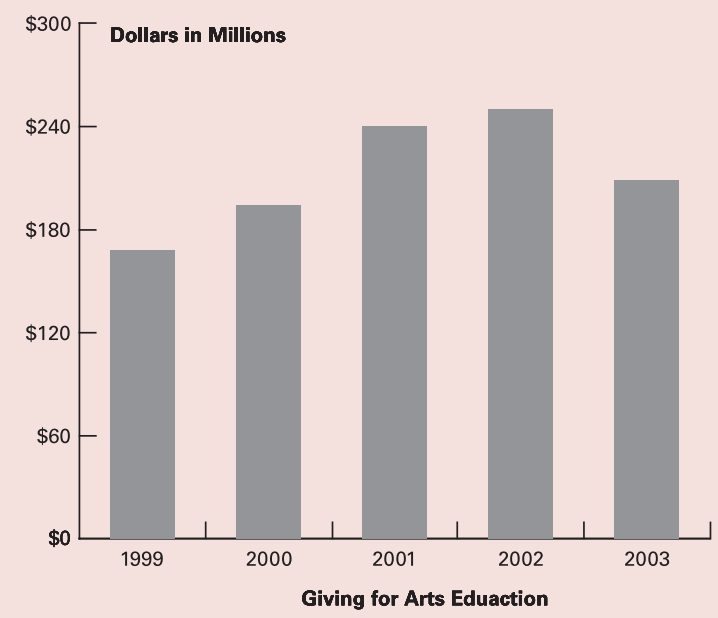

Based on all arts education grants of $\$ 10,000$ or more awarded by 520 larger foundations for 1999,555 for 2000,578 for 2001, 576 for 2002, and 549 for 2003. Only grants to organizations are included. funders in 2003 allocated at least 10 percent of their funding for the field. Those directing the largest shares to arts education included the Windgate Charitable Foundation (61.3 percent), Colburn Foundation (44.2 percent), Jerome L. Greene Foundation (32 percent), and Fred A. Lennon Charitable Trust (25.8 percent).

Finally, recently established foundations constituted a growing segment of arts education funders. In 2003, foundations formed since 1990 represented 16.2 percent of arts education funders in the sample, more than double the 6.3 percent share recorded in 1999 . These newer funders also showed the fastest growth in arts education funding - more than quadrupling their support during this period. Foundations established during this period that ranked among top arts education funders included the Windgate Charitable Foundation (1993), Colburn Foundation (1999), Irene Diamond Fund (1994), and Fred A. Lennon Charitable Trust (1993).

Top 25 Foundations Giving for Arts Education, 2003

\begin{tabular}{|c|c|c|c|c|c|c|c|c|c|}
\hline & \multirow[b]{2}{*}{ Foundation } & \multirow[b]{2}{*}{ State } & \multirow[b]{2}{*}{ Fdn. Type' } & \multicolumn{2}{|c|}{ Grant Dollars } & \multicolumn{2}{|c|}{ Number of Grants } & \multirow{2}{*}{$\begin{array}{l}\text { Arts Education } \\
\text { Giving as a \% of the } \\
\text { Foundation's Giving }\end{array}$} & \multirow{2}{*}{$\begin{array}{c}\% \text { Chg. in Arts } \\
\text { Education Giving, } \\
\text { '99-'03 }\end{array}$} \\
\hline & & & & Amount & $\%$ & No. & $\%$ & & \\
\hline 1. & Kresge Foundation & MI & IN & $9,400,000$ & 4.5 & 9 & 0.3 & 8.7 & 96.7 \\
\hline 2. & Annenberg Foundation & PA & IN & $9,237,334$ & 4.4 & 29 & 0.9 & 5.0 & 96.9 \\
\hline 3. & Windgate Charitable Foundation & AR & IN & $5,641,821$ & 2.7 & 29 & 0.9 & 61.3 & N/A \\
\hline 4. & Starr Foundation & NY & IN & $5,237,500$ & 2.5 & 21 & 0.7 & 3.0 & 648.2 \\
\hline 5. & Charles Stewart Mott Foundation & MI & IN & $4,465,000$ & 2.1 & 5 & 0.2 & 4.7 & 159.2 \\
\hline 6. & Ford Foundation & NY & IN & $4,449,803$ & 2.1 & 40 & 1.3 & 0.9 & 73.1 \\
\hline 7. & William Penn Foundation & PA & IN & $4,422,095$ & 2.1 & 12 & 0.4 & 7.3 & 328.1 \\
\hline 8. & Wallace Foundation & NY & IN & $4,000,000$ & 1.9 & 7 & 0.2 & 9.2 & 13.0 \\
\hline 9. & Surdna Foundation & NY & IN & $3,870,000$ & 1.9 & 35 & 1.1 & 14.8 & 8.9 \\
\hline 10. & William Randolph Hearst Foundation & NY & IN & $2,890,000$ & 1.4 & 31 & 1.0 & 15.3 & -34.9 \\
\hline 11. & William and Flora Hewlett Foundation & $\mathrm{CA}$ & IN & $2,790,000$ & 1.3 & 13 & 0.4 & 1.7 & -0.2 \\
\hline 12. & Colburn Foundation & $\mathrm{CA}$ & IN & $2,666,252$ & 1.3 & 4 & 0.1 & 44.2 & N/A \\
\hline 13. & David and Lucile Packard Foundation & $\mathrm{CA}$ & IN & $2,421,900$ & 1.2 & 22 & 0.7 & 1.4 & -56.3 \\
\hline 14. & Irene Diamond Fund & NY & IN & $2,420,000$ & 1.2 & 10 & 0.3 & 18.4 & 95.2 \\
\hline 15. & Jerome L. Greene Foundation & NY & IN & $2,400,000$ & 1.1 & 1 & 0.0 & 32.0 & 123.3 \\
\hline 16. & Howard Heinz Endowment & PA & IN & $2,317,000$ & 1.1 & 8 & 0.3 & 5.3 & 750.3 \\
\hline 17. & Fred A. Lennon Charitable Trust & $\mathrm{OH}$ & IN & $2,250,000$ & 1.1 & 3 & 0.1 & 25.8 & $\mathrm{~N} / \mathrm{A}$ \\
\hline 18. & Horace W. Goldsmith Foundation & NY & IN & $2,205,000$ & 1.1 & 14 & 0.4 & 5.8 & 623.0 \\
\hline 19. & Wells Fargo Foundation & $\mathrm{CA}$ & CS & $2,002,000$ & 1.0 & 60 & 1.9 & 6.2 & $9,910.0$ \\
\hline 20. & Lied Foundation Trust & NV & IN & $2,000,000$ & 1.0 & 1 & 0.0 & 15.6 & N/A \\
\hline 21. & Brown Foundation & TX & IN & $1,911,014$ & 0.9 & 22 & 0.7 & 4.0 & -0.3 \\
\hline 22. & Freeman Foundation & NY & IN & $1,855,463$ & 0.9 & 18 & 0.6 & 2.4 & 304.2 \\
\hline 23. & John S. and James L. Knight Foundation & $\mathrm{FL}$ & IN & $1,842,000$ & 0.9 & 17 & 0.5 & 1.8 & -6.4 \\
\hline 24. & New York Community Trust & NY & $\mathrm{CM}$ & $1,837,950$ & 0.9 & 67 & 2.1 & 2.0 & 155.3 \\
\hline 25. & MetLife Foundation & NY & $\mathrm{cs}$ & $1,794,000$ & 0.9 & 55 & 1.8 & 9.1 & 412.6 \\
\hline & SUBTOTAL & & & $\$ 86,326,132$ & 41.3 & 533 & 17.0 & & \\
\hline & All other foundations & & & $122,509,933$ & 58.7 & 2,603 & 83.0 & & \\
\hline & TOTAL & & & $\$ 208,836,065$ & 100.0 & 3,136 & 100.0 & & \\
\hline
\end{tabular}

Based on all grants of $\$ 10,000$ or more awarded by 1,010 larger foundations. Of this sample, 549 funders awarded arts education grants. Only grants to organizations are included. ${ }^{1}$ IN=Independent; CS=Corporate-Sponsored; $\mathrm{CM}=$ Community.

$\mathrm{N} / \mathrm{A}=$ Not available. 


\section{Arts Education Funding by Foundation Type}

Independent foundations account for the dominant share of foundation giving for arts education. They provided four-fifths (80.7 percent) of arts education grant dollars and over three-fifths (61.1 percent) of grants in 2003. Still, corporate foundations played an important role in supporting arts education. While they provided a relatively modest 11 percent of grant dollars, corporate foundations accounted for close to one-quarter (22.5 percent) of the number of arts education grants. Similarly, community foundations awarded less than 8 percent of 2003 arts education grant dollars but almost twice that share of grants (15.4 percent).
Independent foundations provided four-fifths of arts education grant dollars in 2003
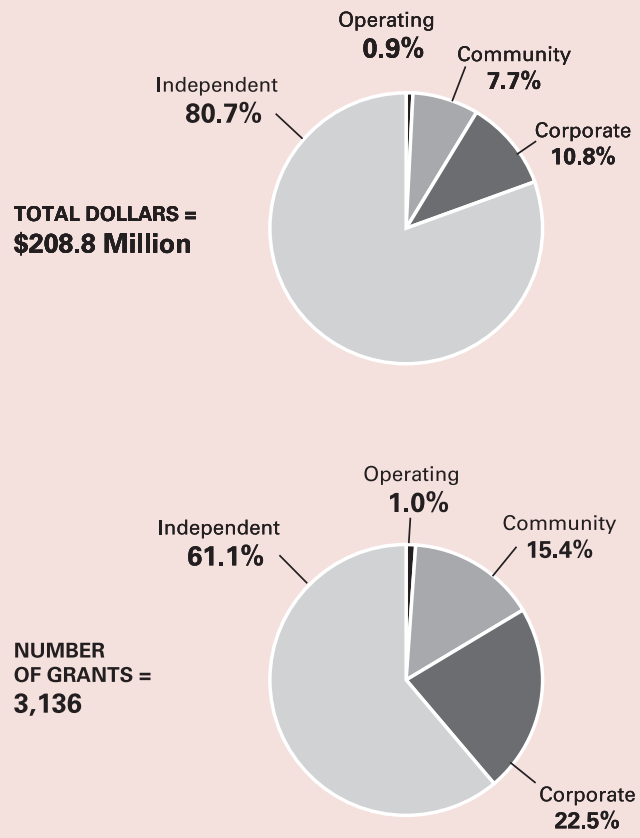

Based on all grants of $\$ 10,000$ or more awarded by 1,010 larger foundations. Of this sample, 549 funders including 385 independent foundations, 108 corporate foundations, 54 community foundations, and two operating foundations) awarded arts education grants. Only grants to organizations are included. 
Close to half of arts education grants in $\mathbf{2 0 0 3}$ were for less than $\$ 25,000$

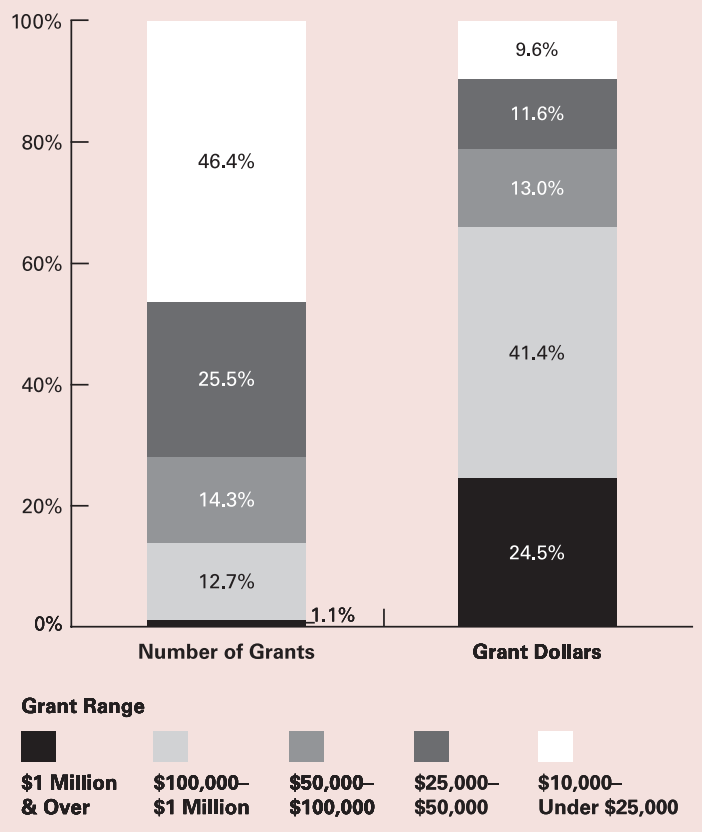

Based on all grants of $\$ 10,000$ or more awarded by 1,010 larger foundations. Of this sample, 549 funders awarded arts education grants. Only grants to organizations are included.

\section{Arts Education Funding by Grant Size}

The vast majority of arts education grants are small. In 2003, close to half ( 46.4 percent) of arts education grants were for less than $\$ 25,000$. By comparison, roughly twofifths (39.9 percent) of foundation grants overall were of this size. The relatively high proportion of smaller arts education grants may reflect a heavier use of program grants, which tend to be smaller on average than most other types of support (for more detail see "Types of Support and Arts Education Funding”). By comparison, arts education grants of at least $\$ 1$ million accounted for only 1.1 percent of the number of grants awarded but nearly one-fourth (24.5 percent) of arts education dollars. As a result, the average arts education grant $(\$ 66,693)$ was close to three times the size of the median, or typical, grant $(\$ 25,000)$.

\section{Chicago Community Trust (IL)}

seeks "to promote systemic change in arts education and strong arts leadership within the

Chicago Public Schools.” Funding supports sequential arts education in dance, music, theater, and visual arts for children in kindergarten through 8th grade. 


\section{Priorities in Arts Education Funding}

\section{PERFORMING ARTS EDUCATION}

Overall, performing arts education accounted for more than half of grant dollars and grants in 2003. Music education constituted the biggest share of performing arts education dollars (40.4 percent), followed by "Other Performing Arts Education" (32.4 percent), which includes funding for multidisciplinary performing arts education institutions and programs. Smaller shares of funding supported theater and dance education. Support for performing arts education rose 60 percent between 1999 and 2003, and growth in this area far exceeded increases in arts education funding overall. Giving was boosted by above-average growth in the number of grants-notably in the areas of dance and theater education. In addition, eight of the ten largest arts education grants in 2003, ranging from $\$ 2$ million to $\$ 3$ million, benefited performing arts education.

Among the largest funders of performing arts education were the Kresge Foundation, which awarded \$7.6 million nationally in capital support ${ }^{3}$ to performing arts education institutions; the Starr Foundation, which gave $\$ 4.4$ million to New York City-based performing arts institutions, mainly for scholarship funds for young artists; the Charles Stewart Mott Foundation, which gave $\$ 4.4$ million to the Flint Institute of Music (MI) for various purposes; the Annenberg Foundation, which gave $\$ 3.5$ million to performing arts education institutions nationally and internationally; and the Surdna Foundation, which distributed over $\$ 3$ million for national programs, including its Talented Students in the Arts Initiative. Several foundations targeted programs for underserved or disadvantaged youth. For example, the SBC Foundation awarded \$200,000 to the Greater Austin Performing Arts Center (TX) to create an arts education program for inner-city schools.
Performing arts education accounted for the largest share of arts education giving in 2003

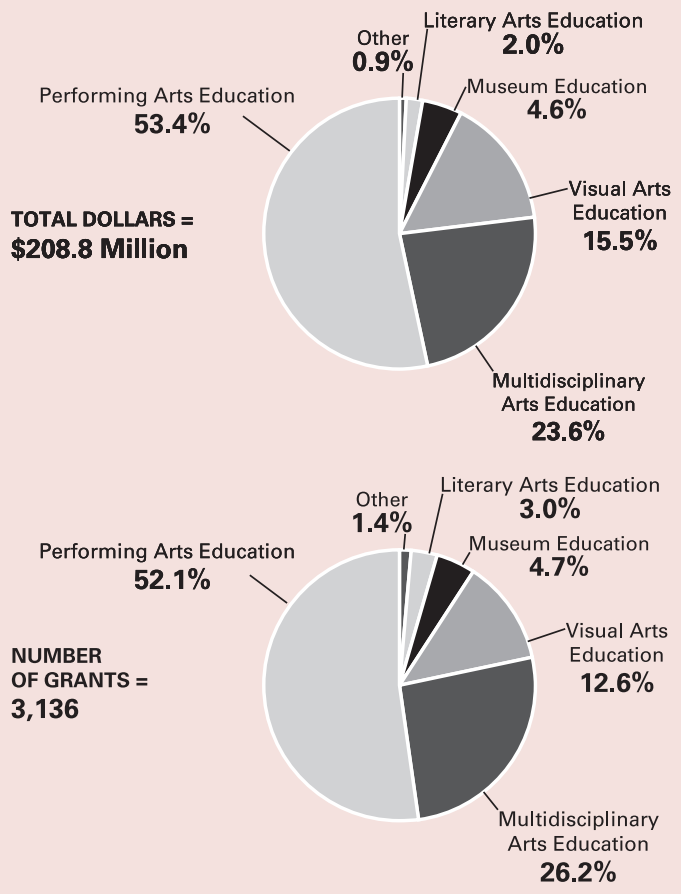

Based on all grants of $\$ 10,000$ or more awarded by 1,010 larger foundations. Of this sample, 549 funder awarded arts education grants. Only grants to organizations are included.

Arts Education Grants by Major Field and Subfield, 2003

\begin{tabular}{|c|c|c|c|c|}
\hline & \multicolumn{2}{|c|}{ Grant Dollars } & \multicolumn{2}{|c|}{ Number of Grants } \\
\hline & Amount & $\%$ & No. & $\%$ \\
\hline Performing Arts Education & $\$ 111,483,520$ & 53.4 & 1,633 & 52.1 \\
\hline Music & $45,073,596$ & 21.6 & 722 & 23.0 \\
\hline Theater & $15,696,912$ & 7.5 & 328 & 10.5 \\
\hline Dance & $14,554,959$ & 7.0 & 234 & 7.5 \\
\hline Other Performing Arts Education & $36,158,053$ & 17.3 & 349 & 11.1 \\
\hline Multidisciplinary Arts Education ${ }^{1}$ & $\$ 49,257,911$ & 23.6 & 823 & 26.2 \\
\hline Cultural/Ethnic Awareness & $2,052,020$ & 1.0 & 34 & 1.1 \\
\hline $\begin{array}{l}\text { Other Multidisciplinary Arts } \\
\text { Education }\end{array}$ & $47,205,891$ & 22.6 & 789 & 25.2 \\
\hline Visual Arts Education & $\$ 32,337,804$ & 15.5 & 395 & 12.6 \\
\hline Museum Education & $\$ 9,666,768$ & 4.6 & 147 & 4.7 \\
\hline Art Museum Education & $6,920,276$ & 3.3 & 84 & 2.7 \\
\hline Other Museum Education & $2,746,492$ & 1.3 & 63 & 2.0 \\
\hline Literary Arts Education & $4,198,127$ & 2.0 & 93 & 3.0 \\
\hline Other & $\$ 1,891,935$ & 0.9 & 45 & 1.4 \\
\hline TOTAL & $\$ 208,836,065$ & 100.0 & 3,136 & 100.0 \\
\hline
\end{tabular}

Based on all grants of $\$ 10,000$ or more awarded by 1,010 larger foundations. Of this sample, 549 funders awarded arts education grants. Only grants to organizations are included.

${ }^{1}$ Includes multipurpose arts education programs and centers. 
Performing arts education showed the greatest growth in grant dollars from 1999 to 2003

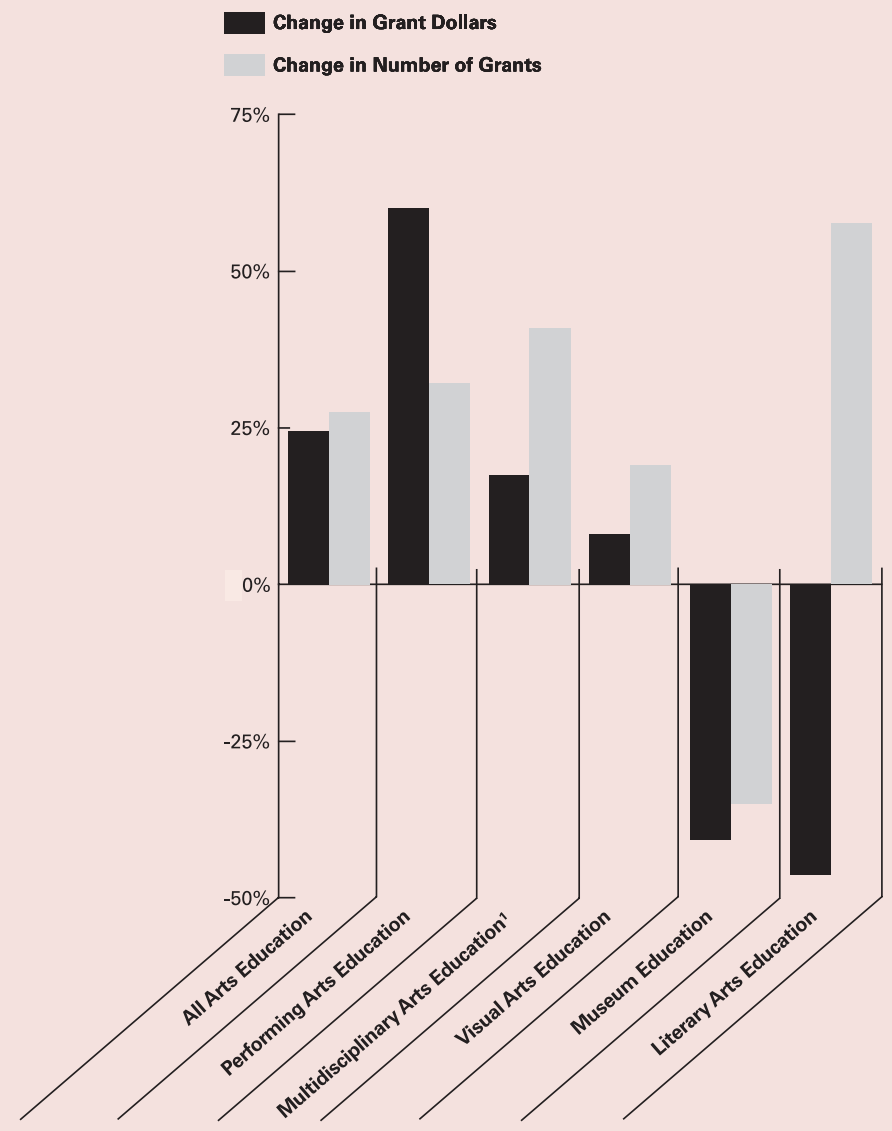

Based on all arts education grants of $\$ 10,000$ or more awarded by 520 larger foundations for 1999 and 549 for 2003. Only grants to organizations are included.

${ }^{1}$ Includes multipurpose arts education programs and centers.

Capital support represented one-quarter of arts education giving in 2003 but had little impact on the overall distribution of grant dollars

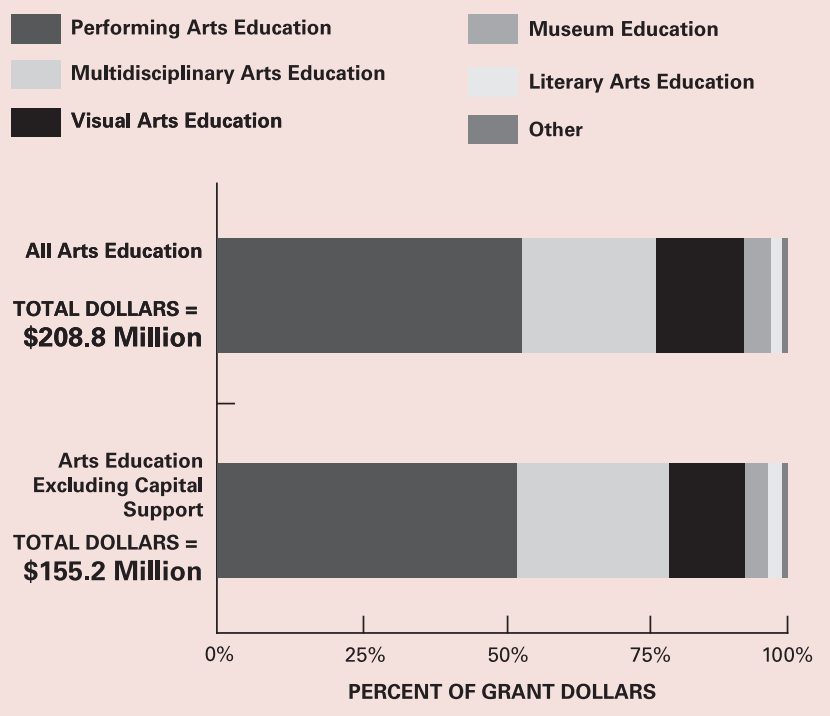

Based on all grants of $\$ 10,000$ or more awarded by 1,010 larger foundations. Of this sample, 549 funder awarded arts education grants. Only grants to organizations are included.

\section{MULTIDISCIPLINARY ARTS EDUCATION}

Funding for multidisciplinary arts education, which includes broad arts-in-education centers and programs, multidisciplinary arts schools, and ethnic arts education programs, grew more slowly than arts education funding overall. Nonetheless, this area accounted for the second largest share of arts education dollars (23.6 percent) and grants (26.2 percent). Moreover, within multidisciplinary arts education, support for broad ethnic arts education programs increased six fold. ${ }^{4}$

The Arkansas-based Windgate Charitable Foundation was the largest funder of multipurpose arts education programs. Windgate gave $\$ 5.1$ million in 24 grants, including a $\$ 2.3$ million award to the Pi Beta Phi Settlement School (TN)—an arts education school—for an artist-in-residence endowment and fellowships; and \$1.6 million to the University of Arkansas Foundation for teacher arts education programs and inschool programs. The second-ranked Annenberg Foundation awarded \$4.5 million, including \$2.5 million to the Center for Arts Education in New York City for continued support of programs in local public schools; and \$1 million for expanded programs of the Inner-City Arts Foundation, which provides arts education programs to underserved school children in partnership with the Los Angeles Unified School District. Other leading funders of arts-in-the-schools and arts and education programs included the David and Lucile Packard, Ford, Knight, Hearst, Kellogg, and MetLife foundations, and the Chicago Community Trust. In the area of ethnic arts education, the Freeman Foundation awarded almost $\$ 1.5$ million to 16 arts institutions nationwide for its Asian Art-Educational Outreach Funding Initiative.

\section{VISUAL ARTS EDUCATION}

Visual arts education, which includes multipurpose visual arts programs and centers and those with a single focus, such as photography or sculpture, received 15.5 percent of arts education dollars in 2003, down from almost 18 percent in 1999. Nonetheless, this area accounted for the third largest share of arts education dollars and grants. Several of the biggest visual arts education grants provided capital support. For example, the Lilly Endowment gave \$1.2 million to the Indianapolis Arts Center, which offers studio art classes to the general public, for a renovation project; and the Keck Foundation gave \$500,000 to the Art Center College of Design in Pasadena to expand public programming by establishing a new campus. Grants were 
also made to colleges and universities for fine arts programs, to museums exclusively for visual arts education programming, and to visual arts education organizations benefiting children and youth. In the latter category, the Agnes Gund Foundation awarded a $\$ 285,000$ general support grant to the New York-based Studio in a School Association; the William Penn Foundation awarded \$250,000 to Philadelphia Mural Arts Advocates for community-based mural arts programs for low-income Philadelphia youth; and the Howard Heinz Endowment gave \$200,000 to the Pittsburgh-based Manchester Craftsmen's Guild for arts-based education programs for disadvantaged public school students. Also included in this subfield were grants to visual arts schools for tuition aid for young visual artists.

\section{MUSEUM ARTS EDUCATION}

Funding for broad-based museum arts education declined between 1999 and 2003, and its share of arts education dollars fell from 9.7 percent to 4.6 percent. The share of number of grants also decreased, from 9.2 percent to 4.7 percent. The majority of support targeted general education activities, facilities, and resources of art museums. Grants also supported educational programs of general purpose, children's, ethnic/folk arts, history, and specialized museums. ${ }^{5}$ Similar to other fields of arts education funding, a few of the very largest museum grants supported capital projects, such as the William Randolph Hearst Foundation's \$500,000 grant to the Los Angeles County Art Museum for an endowed arts education fund. Nevertheless, the vast majority of grant dollars and grants for museum arts education supported programming, including school-based programs.

Corporate foundations were among the most active supporters of museum arts education, with an emphasis on programs for children and youth. For example, the Wells Fargo Foundation awarded \$475,000 for K-12 museum education programs (mainly in California); the SBC Foundation awarded $\$ 333,500$ to museums (mainly in the West) to enhance museum education technology and programs for students; and the MetLife Foundation distributed \$215,000 mainly to children's museums (in various states) for family programs in arts education.
Top 25 Foundations by Share of Giving for Arts Education, 2003

\begin{tabular}{|c|c|c|c|c|c|c|}
\hline & Foundation & State & $\begin{array}{l}\text { Fdn. } \\
\text { Type }^{1}\end{array}$ & Amount & $\begin{array}{c}\text { Arts } \\
\text { Education } \\
\text { Giving as } \\
\text { a \% of the } \\
\text { Foundation's } \\
\text { Giving }\end{array}$ & $\begin{array}{l}\text { No. of } \\
\text { Grants }\end{array}$ \\
\hline 1. & $\begin{array}{l}\text { Windgate Charitable } \\
\text { Foundation }\end{array}$ & AR & IN & $\$ 5,641,821$ & 61.3 & 29 \\
\hline 2. & Colburn Foundation & CA & IN & $2,666,252$ & 44.2 & 4 \\
\hline 3. & $\begin{array}{l}\text { Barbara J. \& Gerald M. Levin } \\
\text { Family Foundation }\end{array}$ & NY & IN & $1,500,000$ & 37.5 & 1 \\
\hline 4. & Baker Street Foundation & CA & IN & $1,485,000$ & 36.8 & 9 \\
\hline 5. & Prudential Foundation & NJ & CS & $1,130,000$ & 33.4 & 8 \\
\hline 6. & $\begin{array}{l}\text { Jerome L. Greene } \\
\text { Foundation }\end{array}$ & NY & IN & $2,400,000$ & 32.0 & 1 \\
\hline 7. & $\begin{array}{l}\text { Idaho Community } \\
\text { Foundation }\end{array}$ & ID & $\mathrm{CM}$ & 12,500 & 26.6 & 1 \\
\hline 8. & $\begin{array}{l}\text { Fred A. Lennon Charitable } \\
\text { Trust }\end{array}$ & $\mathrm{OH}$ & IN & $2,250,000$ & 25.8 & 3 \\
\hline 9. & $\begin{array}{l}\text { Hiawatha Education } \\
\text { Foundation }\end{array}$ & $\mathrm{MN}$ & IN & 82,000 & 24.5 & 2 \\
\hline 10. & $\begin{array}{l}1994 \text { Charles B. Degenstein } \\
\text { Foundation }\end{array}$ & PA & IN & $1,146,100$ & 23.0 & 1 \\
\hline 11. & Jaquelin Hume Foundation & CA & IN & $1,014,550$ & 22.4 & 1 \\
\hline 12. & Kovner Foundation & NJ & IN & $1,000,000$ & 22.3 & 1 \\
\hline 13. & $\begin{array}{l}\text { Helena Rubinstein } \\
\text { Foundation }\end{array}$ & NY & IN & 489,000 & 22.0 & 27 \\
\hline 14. & $\begin{array}{l}\text { Mary Flagler Cary Charitable } \\
\text { Trust }\end{array}$ & NY & IN & 559,000 & 22.0 & 20 \\
\hline 15. & Irene Diamond Fund & NY & IN & $2,420,000$ & 18.4 & 10 \\
\hline 16. & Louis Calder Foundation & CT & IN & 890,011 & 15.8 & 29 \\
\hline 17. & Leighton-Oare Foundation & IN & IN & $1,000,000$ & 15.6 & 2 \\
\hline 18. & $\begin{array}{l}\text { New York Times Company } \\
\text { Foundation }\end{array}$ & NY & CS & 585,000 & 15.6 & 34 \\
\hline 19. & Lied Foundation Trust & NV & IN & $2,000,000$ & 15.6 & 1 \\
\hline 20. & $\begin{array}{l}\text { William Randolph Hearst } \\
\text { Foundation }\end{array}$ & NY & IN & $2,890,000$ & 15.3 & 31 \\
\hline 21. & Surdna Foundation & NY & IN & $3,870,000$ & 14.8 & 35 \\
\hline 22. & Hearst Foundation & NY & IN & $1,575,000$ & 14.5 & 26 \\
\hline 23. & A. D. Henderson Foundation & $\mathrm{FL}$ & IN & 416,922 & 14.4 & 10 \\
\hline 24. & Helen F. Whitaker Fund & PA & IN & 915,000 & 14.2 & 12 \\
\hline 25. & Connelly Foundation & PA & IN & $1,431,781$ & 14.1 & 30 \\
\hline
\end{tabular}

Based on all grants of $\$ 10,000$ or more awarded by 1,010 larger foundations. Of this sample, 549 funders awarded arts education grants. Only grants to organizations are included.

${ }^{1} \mathrm{IN}=$ Independent; $\mathrm{CS}=$ Corporate-Sponsored; $\mathrm{CM}=$ Community. 
Top 25 Recipients of Arts Education Grants, 2003

\begin{tabular}{|c|c|c|c|c|c|c|}
\hline & \multirow[b]{2}{*}{ Recipient } & \multirow[b]{2}{*}{ State } & \multicolumn{2}{|c|}{ Grant Dollars } & \multicolumn{2}{|c|}{ Number of Grants } \\
\hline & & & Amount & $\%$ & No. & $\%$ \\
\hline 1. & Juilliard School & NY & $9,815,000$ & 4.7 & 27 & 0.9 \\
\hline 2. & $\begin{array}{l}\text { Flint Cultural Center } \\
\text { Foundation }\end{array}$ & MI & $4,000,000$ & 1.9 & 2 & 0.1 \\
\hline 3. & Michigan Opera Theater & MI & $3,010,000$ & 1.4 & 2 & 0.1 \\
\hline 4. & Center for Arts Education & NY & $2,850,000$ & 1.4 & 10 & 0.3 \\
\hline 5. & $\begin{array}{l}\text { National Dance Institute New } \\
\text { Mexico }\end{array}$ & NM & $2,585,000$ & 1.2 & 10 & 0.3 \\
\hline 6. & $\begin{array}{l}\text { Colburn School of the } \\
\text { Performing Arts }\end{array}$ & CA & $2,544,252$ & 1.2 & 3 & 0.1 \\
\hline 7. & Jazz at Lincoln Center & NY & $2,385,000$ & 1.1 & 5 & 0.2 \\
\hline 8. & Pi Beta Phi Settlement School & TN & $2,379,844$ & 1.1 & 4 & 0.1 \\
\hline 9. & Cleveland Institute of Music & $\mathrm{OH}$ & $2,241,000$ & 1.1 & 7 & 0.2 \\
\hline 10. & Art Center College of Design & CA & $2,188,500$ & 1.0 & 15 & 0.5 \\
\hline 11. & Philadelphia Museum of Art & PA & $2,049,400$ & 1.0 & 2 & 0.1 \\
\hline 12. & $\begin{array}{l}\text { Community School of Music } \\
\text { and Arts }\end{array}$ & CA & $2,037,600$ & 1.0 & 13 & 0.4 \\
\hline 13. & $\begin{array}{l}\text { Hixson-Lied College of Fine } \\
\text { and Performing Arts at the } \\
\text { University of Nebraska }\end{array}$ & $\mathrm{NE}$ & $2,000,000$ & 1.0 & 1 & 0.0 \\
\hline 14. & Carnegie Institute & PA & $1,900,000$ & 0.9 & 4 & 0.1 \\
\hline 15. & $\begin{array}{l}\text { Pennsylvania Academy of the } \\
\text { Fine Arts }\end{array}$ & PA & $1,882,070$ & 0.9 & 8 & 0.3 \\
\hline 16. & California Institute of the Arts & CA & $1,788,381$ & 0.9 & 17 & 0.5 \\
\hline 17. & $\begin{array}{l}\text { Children's Theater Company } \\
\text { and School }\end{array}$ & $\mathrm{MN}$ & $1,766,500$ & 0.8 & 21 & 0.7 \\
\hline 18. & $\begin{array}{l}\text { University of Arkansas } \\
\text { Foundation }\end{array}$ & AR & $1,673,056$ & 0.8 & 5 & 0.2 \\
\hline 19. & Settlement Music School & PA & $1,670,000$ & 0.8 & 8 & 0.3 \\
\hline 20. & $\begin{array}{l}\text { San Francisco Conservatory } \\
\text { of Music }\end{array}$ & CA & $1,668,550$ & 0.8 & 9 & 0.3 \\
\hline 21. & $\begin{array}{l}\text { Interlochen Center for the } \\
\text { Arts }\end{array}$ & MI & $1,538,536$ & 0.7 & 10 & 0.3 \\
\hline 22. & Inner-City Arts Foundation & CA & $1,518,334$ & 0.7 & 8 & 0.3 \\
\hline 23. & School of American Ballet & NY & $1,452,800$ & 0.7 & 22 & 0.7 \\
\hline 24. & $\begin{array}{l}\text { Museum of Fine Arts, } \\
\text { Houston }\end{array}$ & $\mathrm{TX}$ & $1,440,500$ & 0.7 & 4 & 0.1 \\
\hline \multirow[t]{4}{*}{25.} & Indianapolis Art Center & IN & $1,440,203$ & 0.7 & 4 & 0.1 \\
\hline & SUBTOTAL & & $\$ 59,824,526$ & 28.6 & 221 & 7.0 \\
\hline & All other recipients & & $149,011,539$ & 71.4 & 2,915 & 93.0 \\
\hline & TOTAL & & $\$ 208,836,065$ & 100.0 & 3,136 & 100.0 \\
\hline
\end{tabular}

\section{LITERARY ARTS EDUCATION}

Funding for literary arts education accounted for 2 percent of arts education support in 2003, down from almost 5 percent in 1999. Nonetheless, the number of grants awarded increased by more than half. Since even the largest funders of literary arts education reported, on average, two or fewer grants, this finding suggests that the number of funders has increased. Within this subfield, types of programs supported ranged from undergraduate and graduate-level literature programs to school-based and community-based programs in poetry, literature, reading, and creative writing. In the former category, the E. Rhodes \& Leona B. Carpenter Foundation awarded $\$ 600,000$ to Mary Baldwin College (VA) for a new graduate-level program in Shakespeare and the Renaissance. In the latter area, the Dekko Foundation gave almost \$200,000 to the East Noble School Corporation (IN) for writing programs; the Evelyn and Walter Haas, Jr. Fund awarded $\$ 150,000$ to the Developmental Studies Center (CA) to expand dissemination and training for after-school literature programs; and the Oprah Winfrey Foundation gave a $\$ 50,000$ general support grant to Literature for All of Us (IL), a book club for low-income young mothers to explore the rewards of reading and writing.

\section{Surdna Foundation (NY),}

through its nationwide Arts Program, seeks to help 11 to 18 -year-olds "explore their identity and relationship to the world through highimpact, long-term experiences creating art with accomplished professional artists." The foundation also supports efforts to strengthen teaching by artists who work with teens. 


\section{Arts Education Funding by Recipient Type}

Arts education giving overwhelmingly targets arts organizations, with entities that focus exclusively on performing arts education, post-secondary arts education, and multidisciplinary arts education benefiting from the largest shares of support. In 2003, nearly four-fifths of arts education grant dollars and grants supported arts organizations. Performing arts education organizationse.g., the National Dance Institute New Mexico and the Colburn School of the Performing Arts (CA) - accounted for the single largest share of funding (14.1 percent). Following these organizations closely by share of grant dollars were arts-focused higher and graduate educational institutions (13.8 percent) - e.g., the Cleveland Institute of Art and the Juilliard School (NY) — and multidisciplinary arts education organizations (11.4 percent) - e.g., the Center for Arts Education (NY) and the Inner-City Arts Foundation (CA). Other arts organizations receiving at least 5 percent of arts education giving in 2003 included music organizations, museums, and theaters.

General-purpose higher and graduate educational institutions and elementary and secondary schools accounted for roughly 18 percent of grant dollars and 16 percent of grants in 2003, and these shares were down from 1999. The majority of this support targeted arts programs of higher and graduate educational institutions. By comparison, elementary and secondary schools received less than 6 percent of grant dollars, down from close to 10 percent in 1999. In general, this finding reflects the disinclination of most grantmakers to provide funding to public elementary and secondary schools directly.

Finally, the number of organizations in the sample benefiting from arts education support jumped by onequarter between 1999 and 2003, from just over 1,400 to 1,800 . This gain roughly paralleled the growth in number of arts education grants and suggests that foundations were making a conscious effort to distribute their arts education funding more broadly. On average, organizations received two grants in 2003, unchanged from 1999. Some institutions, however, received far more grants. Among the top 25 recipients, Juilliard received the largest number of grants (27), followed by the School of American Ballet (22).
Arts Education Grants by Recipient Type, 2003

\begin{tabular}{|c|c|c|c|c|}
\hline \multirow[b]{2}{*}{ Recipient Type } & \multicolumn{2}{|c|}{ Grant Dollars } & \multicolumn{2}{|c|}{ Number of Grants } \\
\hline & Amount & $\%$ & No. & $\%$ \\
\hline Arts Organizations & $\$ 165,672,690$ & 79.3 & 2,456 & 78.3 \\
\hline Performing Arts Organizations & $72,048,985$ & 34.5 & 1,268 & 40.4 \\
\hline $\begin{array}{l}\text { Performing Arts Education } \\
\text { Organizations }\end{array}$ & $29,429,039$ & 14.1 & 456 & 14.5 \\
\hline Music Organizations & $19,387,457$ & 9.3 & 311 & 9.9 \\
\hline Theaters & $11,501,025$ & 5.5 & 253 & 8.1 \\
\hline Dance Organizations & $5,355,719$ & 2.6 & 132 & 4.2 \\
\hline Performing Arts Centers & $5,006,445$ & 2.4 & 74 & 2.4 \\
\hline Other Performing Arts Groups & $1,369,300$ & 0.7 & 42 & 1.3 \\
\hline $\begin{array}{l}\text { Arts-Focused Higher Educational } \\
\text { Institutions }\end{array}$ & $28,902,962$ & 13.8 & 224 & 7.1 \\
\hline $\begin{array}{l}\text { Multidisciplinary Arts Educa- } \\
\text { tion Organizations }\end{array}$ & $23,806,553$ & 11.4 & 421 & 13.4 \\
\hline Museums & $17,973,039$ & 8.6 & 237 & 7.6 \\
\hline Visual Arts Organizations & $7,833,083$ & 3.8 & 116 & 3.7 \\
\hline Multidisciplinary Arts Centers & $7,221,810$ & 3.5 & 63 & 2.0 \\
\hline Arts Councils & $2,155,438$ & 1.0 & 29 & 0.9 \\
\hline Ethnic/Folk Arts Organizations & 989,800 & 0.5 & 20 & 0.6 \\
\hline Other Arts Organizations ${ }^{1}$ & $4,741,020$ & 2.3 & 78 & 2.5 \\
\hline $\begin{array}{l}\text { General-Purpose Educational } \\
\text { Institutions }\end{array}$ & $\$ 36,615,803$ & 17.5 & 503 & 16.0 \\
\hline Higher Educational Institutions & $22,667,378$ & 10.9 & 229 & 7.3 \\
\hline Elementary/Secondary Schools & $11,814,118$ & 5.7 & 225 & 7.2 \\
\hline Other Educational Institutions & $2,134,307$ & 1.0 & 49 & 1.6 \\
\hline Human Service Agencies & $4,043,476$ & 1.9 & 120 & 3.8 \\
\hline Youth Development Organizations & $2,091,952$ & 1.0 & 58 & 1.8 \\
\hline Other Human Service Agencies & $1,951,524$ & 0.9 & 62 & 2.0 \\
\hline $\begin{array}{l}\text { Community Improvement } \\
\text { Organizations }\end{array}$ & $1,287,000$ & 0.6 & 18 & 0.6 \\
\hline Other Organizations & \$ $1,217,096$ & 0.6 & 39 & 1.2 \\
\hline TOTAL & $\$ 208,836,065$ & 100.0 & 3,136 & 100.0 \\
\hline
\end{tabular}

Based on all grants of $\$ 10,000$ or more awarded by 1,010 larger foundations. Of this sample, 549 funders awarded arts education grants. Only grants to organizations are included.

${ }^{1}$ Includes arts advocacy organizations, multipurpose arts associations, governmental art agencies, arts fund raising organizations, film/video groups, artist's services organizations, and other arts organizations. 
Nearly three-fifths of arts education grants targeted children and youth in 2003
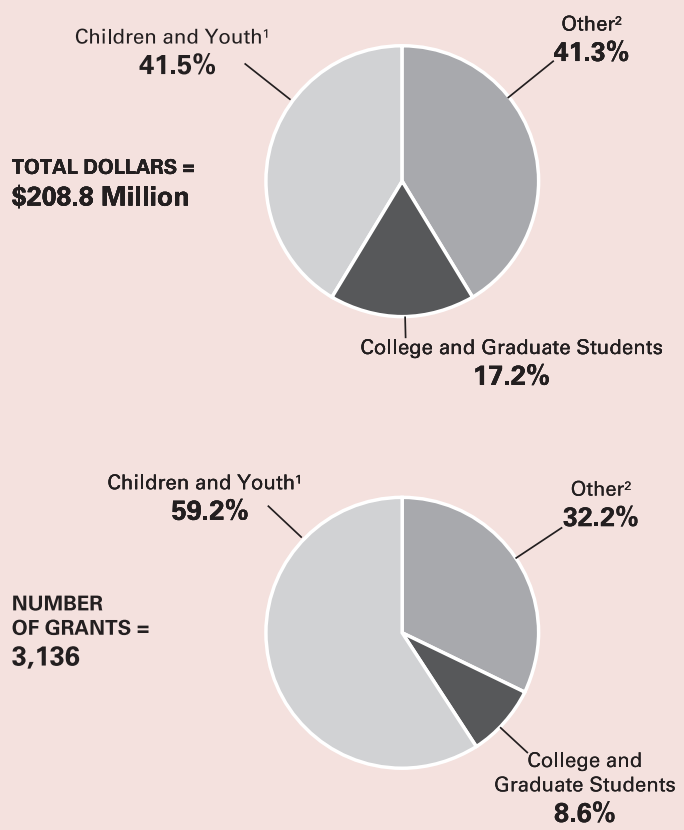

Based on all grants of $\$ 10,000$ or more awarded by 1,010 larger foundations. Of this sample, 549 funder awarded arts education grants. Only grants to organizations are included.

'Includes support for in-school and other arts education, including early childhood arts education.

${ }^{2}$ Includes grants intended mainly to provide arts education for the broad public by non-degree-granting arts institutions and other community organizations. It also includes grants to support the professional evelopment or emerging artists and grants lacking surficient descriptive information to be coded for a ge-specific target group.

\section{Arts Education Funding by Target Group}

Arts education funding reaches all age groups, from toddlers through the aging. Yet reflecting both the importance of the arts in early intellectual development and later academic success and of cultivating each new generations' artistic skills and appreciation of the arts, a majority of foundation arts education grants targeted children and youth. ${ }^{6}$ In fact, almost three-fifths of the number of arts education grants and over two-fifths of grant dollars were identified as supporting children and youth in 2003.

Arts education funding for children and young people supported programs both within and outside of schools, and reached down to the youngest children. ${ }^{7}$ For example, giving in the latest sample included a $\$ 700,000$ grant from the W.K. Kellogg Foundation to the Ottawa Coalition (Toledo, $\mathrm{OH}$ ) for a collaborative effort enhancing elementary school readiness through integrating arts into preschool curriculum; and a $\$ 600,000$ grant from the Wallace Foundation to the Community Music School of Springfield (MA) to educate early childhood teachers at multiple community sites to integrate music into their daily classroom activities.

The Foundation Center's Grants Classification System does not separately code grants awarded to benefit young adults. However, funding for college and graduate-level arts education does provide a rough proxy for this support. Approximately 9 percent of the number of 2003 arts education grants and close to double this share of grant dollars (17.2 percent) funded arts education-related projects at the post-secondary level. Grants ranged from an endowment award for the Juilliard School (Starr Foundation), to project support for the music and arts program at Susquehanna University (1994 Charles B. Degenstein Foundation), to capital funding for construction of a performing arts facility with rehearsal studios and classrooms at Ursinus College (Kresge Foundation).

Finally, close to one-third of arts education grants and two-fifths of grant dollars in 2003 either supported arts education without regard to age through non-degreegranting institutions, such as museums and performing arts centers, or could not be coded by age due to a lack of sufficient information about the grant's intended purpose. For example, the Charles Stewart Mott Foundation provided $\$ 4.4$ million to the Flint Institute of Music, which provides learning through music and dance "whether you're six weeks old or sixty." 


\section{Arts Education Funding for Vulnerable Populations}

Within their arts education giving, some foundations direct support to vulnerable or underserved populations, such as ethnic or racial minorities and the economically disadvantaged. This giving targets both subsets of children and youth - the predominant beneficiaries of arts education support-and others. For example, the Prudential Foundation made a $\$ 1$ million grant to the Alvin Ailey Dance Foundation to endow the Alvin Ailey Arts-in-Education Fund to support ongoing dance residencies for minority youth in Newark and Trenton (NJ); and the William Penn Foundation provided a $\$ 660,000$ grant to the Philadelphia-based Settlement Music School for renovation and construction of a new facility in Camden (NJ) and for marketing and outreach activities and financial aid for low-income Camden residents.

In fact, arts education funders directed a slightly larger share of support for ethnic or racial minorities than was recorded for overall grant dollars in 2003-9.4 percent of arts education dollars compared with 8 percent for all grant dollars-suggesting that grantmakers were making a concerted effort to reach these groups. Smaller shares of arts education grant dollars could be identified as benefiting the economically disadvantaged ( 8.7 percent), women and girls ( 1.2 percent), and the disabled ( 0.6 percent). The corresponding shares for overall foundation giving were considerably higher: 15.1 percent for the economically disadvantaged, 7.3 percent for women and girls, and 3 percent for the disabled. These findings suggest that the vast majority of arts education giving is intended to benefit populations in specific age ranges broadly, or the broad public (e.g., families).
Close to one-tenth of arts education grants specified ethnic or racial minorities in 2003

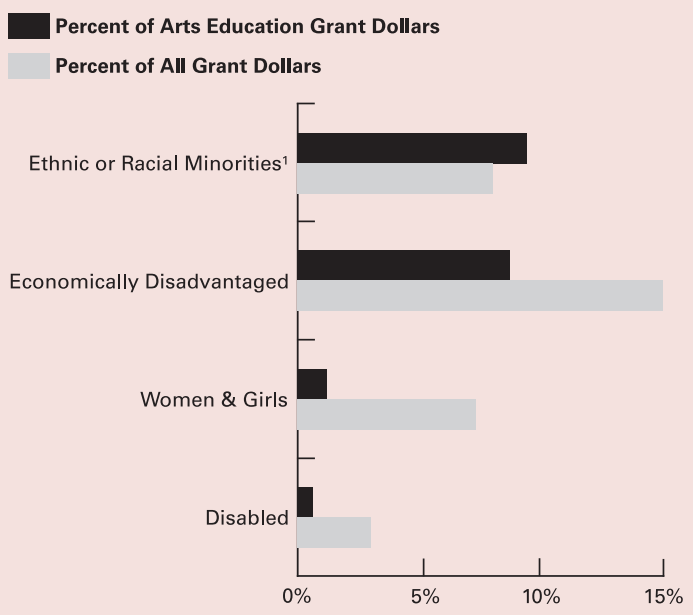

Based on all grants of $\$ 10,000$ or more awarded by 1,010 larger foundations. Only grants to organizations are included.

${ }^{1}$ Coding for these groups generally includes only "domestic" populations. Over seas grants are only coded for ethnic or racial minorities if they specifically mention a benefit for a particular minority group.

\section{Walter and Elise Haas Fund (CA)}

supports arts education for $\mathrm{K}-12$ public school children in San Francisco and Alameda counties, California. It emphasizes extending opportunities for quality, in-depth arts study to young people from low-income families who are attending schools with limited arts programs, as well as out-of-school arts programs that bring together young people from a variety of backgrounds, cultures, and life experiences.

\section{William Randolph Hearst Foundation and Hearst Foundation (NY)}

support programs that "enrich the lives of young people by engaging them in cultural activities, primarily through arts-in-education programs."

They provide grants for on-site and outreach educational activities addressing "the lack of arts programming in pre-kindergarten through 12th grade curricula." 
Northeastern funders awarded over two-fifths of arts education grant dollars in 2003

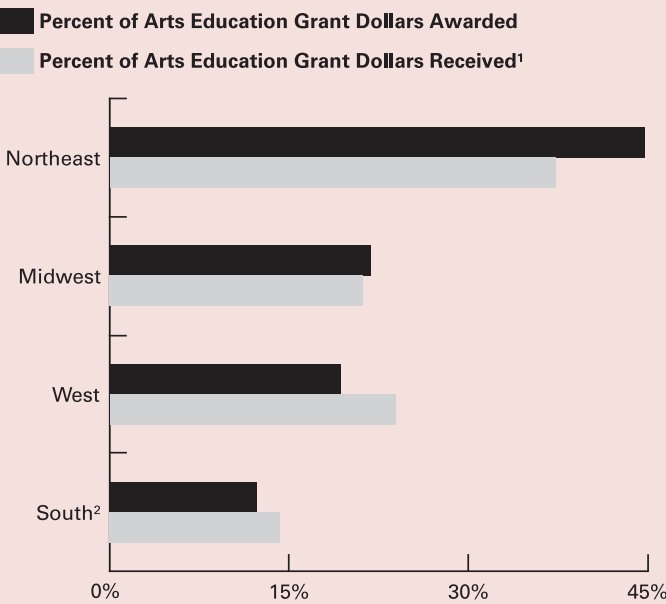

Based on all grants of $\$ 10,000$ or more awarded by 1,010 larger foundations. Of this sample, 549 funders awarded arts education grants. Only grants to organizations are included.

${ }^{1}$ Excludes 48 arts education grants totaling $\$ 4.9$ million awarded outside the United States.

${ }^{2}$ Figures for the South exclude the District of Columbia, which represents 1.8 percent of all grant dollars awarded and 3 percent of grant dollars received.

\section{Arts Education Funding by Funder and Recipient Region}

Led by foundations based in New York and Pennsylvania, the Northeast provided by far the largest share of arts education funding in 2003 (44.8 percent). In fact, seven out of the top ten arts education funders were located in the Northeast, including the second-ranked Annenberg Foundation, fourth-ranked Starr Foundation, and fifthranked Ford Foundation. The Midwest accounted for the second largest share of arts education grant dollars awarded (21.8 percent), followed by the West (19.3 percent) and the South (12.3 percent).

Given that the Northeast is home to many of the largest arts education funders and prominent arts education institutions, it is not surprising that organizations in the region received the bulk of grant dollars (37.3 percent). Eight of the top 25 recipients of arts education giving were based in the Northeast, led by the Juilliard School, which received $\$ 9.8$ million. ${ }^{8}$ Following the Northeast by share of grant dollars received were organizations in the West (23.9 percent)—primarily in California-Midwest (21.6 percent), and South (14.3 percent).

Nearly all arts education grant dollars supported domestic programs. Only 1.5 percent targeted cross-border recipients in 2003, while an equal 1.5 percent share funded U.S.-based international arts education programs. By comparison, 15 percent of overall grant dollars provided international support.

\section{Dana Foundation (NY)}

supports training for in-school arts specialists and professional artists to teach performing arts in New York City, Los Angeles, and District of Columbia public schools. It plans to launch

a similar initiative in rural areas in 2006.

The foundation has also created the Dana Arts and Cognition Consortium to study the impact of arts training on general cognition. 


\section{Types of Support and Arts Education Funding}

Arts education funding tends to be very targeted, with the majority of giving directed to specific programs and projects. In 2003, 54.1 percent of arts education grant dollars provided program support, compared to a roughly 44 percent share for the sample overall. Conversely, operating support represented 15.2 percent of arts education funding, compared to a notably larger 21.8 percent of giving across subject areas. While there are large organizations and educational institutions working exclusively in the area of arts education, these findings reflect the fact that most arts education is taking place in programs conducted by large and small arts and cultural organizations, and by educational institutions.

Interestingly, nearly 27 percent of arts education funding in 2003 came through capital support. Yet, while support targeted large arts educational institutions, such as the Juilliard School and the Pi Beta Phi Settlement School, this funding also provided grant dollars for major capital projects that included a relatively smaller arts education component. For example, the Kresge Foundation made a $\$ 2$ million challenge grant to Jazz at Lincoln Center for construction of performance venues, a broadcasting center, and classrooms. ${ }^{9}$

Finally, student aid funds provided to arts and educational organizations garnered 7.5 percent of arts education grantmaking, surpassing the 4.6 percent share record for overall giving. Most of this funding supported fellowships and scholarships.
Over half of arts education grant dollars targeted specific projects in 2003, surpassing the overall share

Percent of Arts Education Grant Dollars

Percent of All Grant Dollars

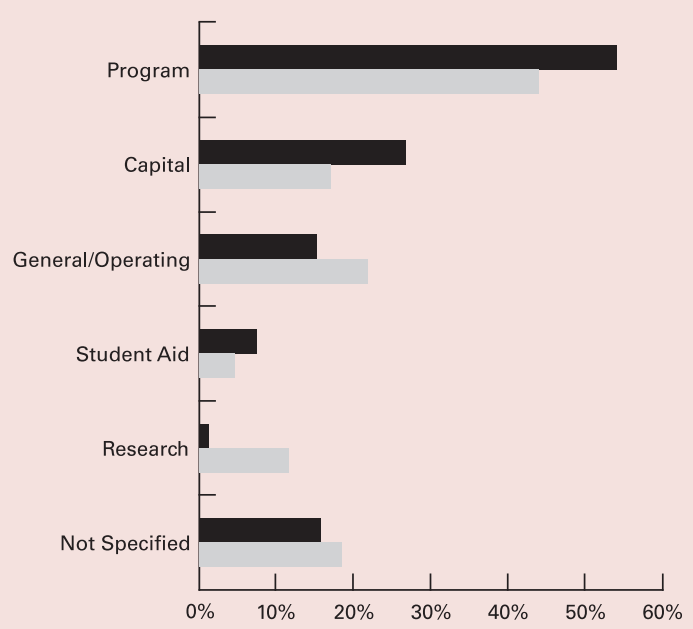

Based on all grants of $\$ 10,000$ or more awarded by 1,010 larger foundations. Only grants to organizations are included.

\section{Geraldine R. Dodge Foundation (NJ)} supports opportunities for New Jersey children to "discover their humanity through meaningful engagement with the arts." The foundation also supports professional development for arts education teachers. 


\section{Looking Ahead}

Although foundation funding for arts education declined from 2002 to 2003, prospects for the field remain encouraging. The recovery in foundation assets that began in 2003 should help strengthen giving for arts education, among other fields and disciplines. The emergence of more recently established grantmakers with an interest in arts education also augers well for the field. Yet even with these additional funders, an uneven economic recovery and continuing fluctuations in stock market performance suggest that growth in giving will occur at a more modest pace than was recorded in the late 1990s.

In this environment, maintaining and growing foundation support for arts education will remain a critical priority. Global competition will only increase the demand for a highly educated labor force with creative skills, while continuing government shortfalls may further reduce the access of young people-especially those least well off-to even basic arts education. Foundations have served as key proponents and supporters of arts education, and that role will likely expand in the years ahead.

\section{ENDNOTES}

1. See Ellen Winner et al., "The Arts and Academic Improvement: What the Evidence Shows: Executive Summary of the Harvard Project Zero Reviewing Education and the Arts Project (REAP)" in The Journal of Aesthetic Education (Volume 34, nos. 3/4 Fall/Winter, 2000). For a summary of main arguments for supporting the arts, see Thomas L. Birch, "The Arts in Public Policy: An Advocacy Agenda" in The NASAA [National Assembly of State Arts Agencies] Advocate (Volume VI, Issue No. 1, 2002).

2. For figures on foundation funding for arts education in 1996 based on a narrower definition of the field, see Loren Renz and Steven Lawrence, Arts Funding: An Update on Foundation Trends, Third Edition (New York: The Foundation Center, 1998), pp. 48-49.

3. Capital support accounted for close to 26 percent of arts education giving in 2003 and was relatively evenly distributed among the major arts education fields. For example, performing arts education represented approximately 53 percent of overall grant dollars in the latest sample and a nearly identical share when capital support was excluded.

4. Not all grants related to ethnic arts education are captured in the multidisciplinary arts education subfield. For example, some of these grants were included in visual arts and in performing arts education.

5. Grants for science museum education programs were excluded from this analysis.

6. For the purposes of this analysis, "children and youth" are defined as newborns through 19 -year-olds.

7. In 2003 , foundations provided 37 arts education grants totaling $\$ 2.8$ million exclusively for children under 5 years old. By comparison, sampled foundations made 26 arts education grants totaling $\$ 1.3$ million for these youngest children in 1999.

8. If capital grants were excluded, the Juilliard School's arts education support would decrease to $\$ 6.7$ million. However, it would continue to rank as the top recipient organization in 2003.

9. Given that it is not possible to apportion such grants, the full value of the grant has been counted toward arts education. 


\section{RESOURCES}

Annenberg Institute for School Reform at Brown University. The Arts and School Reform: Lessons and Possibilities from the Annenberg Challenge Arts Projects. February 2003.

Birch, Thomas L. "The Arts in Public Policy: An Advocacy Agenda" in The NASAA [National Assembly of State Arts Agencies] Advocate, Volume VI, Issue No. 1, 2002.

Catterall, James S. "Education Policy Implications of Recent Research on the Arts and Academic and Social Development" in Journal for Learning Through Music, Summer 2003.

Ellis, Dawn M. and Craig Dreeszen. For the Greater Good: A Framework for Advancing State Arts Education Partnerships. Washington, DC: National Assembly of State Arts Agencies, March 2003.

Fineberg, Carol. Creating Islands of Excellence: Arts Education as a Partner in School Reform. New Hampshire: Heinemann, 2004.

Fiske, Edward B. (ed.) "Champions of Change: the Impact of the Arts on Learning." Washington, DC: Arts Education Partnership and the President's Committee on the Arts and the Humanities, 1999.

McCarthy, Kevin F. et al. Gifts of the Muse: Reframing the Debate About the Benefits of the Arts. California: RAND Corporation, 2004.

Redmond, Robin and Nick Rabkin (eds.) Putting the Arts in the Picture: Reframing Education in the 21st Century. Chicago, IL: Columbia College, 2004.

Renz, Loren and Steven Lawrence. Arts Funding: An Update on Foundation Trends (Third Edition). New York: The Foundation Center, 1998.

Renz, Loren and Steven Lawrence. "Foundation Grants to Arts and Culture, 2003: A One-Year Snapshot" in Grantmakers in the Arts Reader, Volume 15, No. 2, Summer 2005.

Winner, Ellen et al. "The Arts and Academic Improvement: What the Evidence Shows: Executive Summary of the Harvard Project Zero Reviewing Education and the Arts Project (REAP)" in The Journal of Aesthetic Education, Volume 34, nos. 3/4 Fall/Winter, 2000. Available from www.pz.harvard.edu/Research/Reap/ REAPExecSum.htm, Internet, accessed 8/9/2005. 


\section{HEADQUARTERS}

New York

79 Fifth Avenue

N ew York, N Y 10003-3076

Tel: 212-620-4230

Fax: 212-807-3677

\section{WEB SITE}

www.fdncenter.org

\section{FIELD OFFICES}

\section{Atlanta}

50 Hurt Plaza, Suite 150

Atlanta, G A 30303-2914

Tel: 404-880-0094

Fax: 404-880-0087

\section{Cleveland}

1422 Euclid Avenue, Suite 1600

Cleveland, OH 44115-2001

Tel: 216-861-1934

Fax: 216-861-1936

\section{San Francisco}

312 Sutter Street, Suite 606

San Francisco, CA 94108-4323

Tel: 415-397-0902

Fax: 415-397-7670

\section{Washington, DC}

1627 K Street, N W, Third Floor W ashington, DC 20006-1708

Tel: 202-331-1400

Fax: 202-331-1739 